\title{
The Background to Language Change in Hong Kong
}

\section{Godfrey Harrison and Lydia K.H. So}

Speech \& Hearing Sciences, The University of Hong Kong, 5/F Prince Philip

Dental Hospital, 34 Hospital Road, Hong Kong

This paper gives the background to language change in Hong Kong. It surveys the great changes that have taken place over the last 50 years and it situates Hong Kong as the greatest of Cantonese cities. This approach makes apparent how fast and how much Hong Kong has changed and is changing demographically, economically, politically, socially and technologically. Because language and at least four of these five aspects are interwoven, the need to deal with language in Hong Kong has been inescapable even if its manifestations were often unpredictable. The paper also reminds the reader of the greater context, showing some of the complex exchange networks that bind the Cantonese language community and making clear Hong Kong's central position in intra-Chinese relations.

\section{Introduction}

Hong Kong, a sliver of Asian mainland and a clutch of nearby islands, has an area of 1092 square kilometres (422 square miles): much smaller than Majorca or Rhode Island but notably bigger than Anglesey. Its population is 6.3 million people (cf. Hong Kong Monthly Digest of Statistics, April 1996): a little fewer than Greater London's, somewhat more than that of the San Francisco-Oakland metropolis'. Hong Kong, in the Pearl River delta, borders the Shenzhen Special Economic Zone, set up in Guangdong Province, in the People's Republic of China, and is just south of the tropic of Cancer on the western rim of the Pacific Ocean. 'Kong' anglicises the Cantonese word for 'harbour' and Hong Kong's harbour and position have been and remain great assets. Most Hong Kong people work in densely built, often reclaimed, strips that sprawl back to the hills from either side of the harbour which is a channel between Hong Kong Island and the Kowloon peninsula.

People who have lived in Hong Kong for years and have then been away for some months commonly remark, on returning, how greatly the place has changed. They do this after having been used to, or at least aware of, Hong Kong's rapid changes.

Against this background, our interests are the speed, range and unevenness of change in Hong Kong. We claim that in Hong Kong change affects almost everyone, almost all the time, even though a few islets of continuity, like the Mai Po marshes, the lantern festivals and the tramcars endure. In this engulfing pattern of great change and limited conservatism, aspects of language contrast as clearly as fast food with bamboo chop sticks or becoming the world's fifth busiest foreign exchange market with pawnshops. One question then is: why have many of the facts of language use in Hong Kong changed dramatically since 1946, while others have remained relatively untouched? 


\section{The Last Fifty Years}

In June 1946, Hong Kong probably had fewer than one and a half million people (cf. population estimates in the Annual Report on Hong Kong for the year 1946). In that year, the population was readjusting to British colonial rule after an interim military administration had governed the colony through the summer of 1945, when Japan relinquished its occupation of Hong Kong which had begun on Christmas Day, 1941. 'During the Pacific war', the Report notes, 'very heavy material damage had been caused through military operations, looting and neglect' (Hong Kong, 1947: 1). It goes on to characterise how the administration set about re-establishing civil society. 'Whatever was most urgent was done in the easiest and quickest way. Whatever could be postponed was forgotten for the time'. In many ways this typifies the development of Hong Kong over the past 50 years in which very intense urban renewal has resulted from commercial operations, industry and tourism, and in which language use has changed, too.

Today, 50 years on, the people of Hong Kong are adjusting to the prospect of the conclusion, on 1 July 1997, of British colonial rule and the transformation of Hong Kong into a Special Administrative Region of China, purportedly for the following 50 years. China will then manifest its policy of 'one country, two systems': two legal codes, two kinds of passport, two currencies, two prescribed sides of the road on which to drive, two sets of membership of international trade organisations and numerous other parallels.

Only about a fifth of Hong Kong's present population was alive in 1946; a much larger percentage has experienced changes of political framework, not just of government. The proclamation of the People's Republic of China (PRC) on 1 October 1949 had been preceded by hundreds of thousands of refugees leaving China for Hong Kong; others kept coming after the establishment of China's Communist administration. Among these refugees were many from Guangdong province or from Shanghai and other commercial centres in China. These refugees brought drive and money that have helped Hong Kong to become more commercially successful than the once pre-eminent Shanghai. The influence of Hong Kong business empires which began in the 1950s extended worldwide by the 1990s. Refugees from China became 'at home' in Hong Kong partly through adapting and partly through sustaining their own ways, for example in cooking and in speech - as restaurants, clan associations and schools in Hong Kong still demonstrate.

Hong Kong people have been survivors more than the inhabitants of most other indisputably rich modern societies have needed to be over the last few decades. Their ability to survive is true actuarially (current female life expectancy is 81; the male figure is 76), and it is true historically: China's revolution of 1949 (38 years after the first Republic began), the Korean War (1950-53), the Great Leap Forward in China (1958), the Chinese Cultural Revolution (especially in 1966 and 1967), and the Tiananmen Square demonstrations and massacre (1989) all came after the Pacific War that directly and hugely affected people who live in Hong Kong today. More than recency justifies mentioning the Tiananmen massacre alongside an international war and the only two events of the last 50 years that put flats on the graph of China's population growth (Jing Qicheng, 1994). In Hong Kong the Tiananmen events twice brought about a million people onto the streets 
of Hong Kong Island. During the second half of 1989 and in 1990 tens of thousands of families sent somebody overseas to gain a passport that would allow residence there. The coinage 'tai hung yan' (astronaut) came to mean just such a person; the passports could mean survival. It was not wholly unlike the movements of 40 years before.

This impulse for people from Hong Kong to go, mostly to Australia, Canada, New Zealand or the USA, then return a few years later with new passports in hand, has added to the number of fluent English speakers in Hong Kong. A like impulse, at about the same time, led a notable number of people to join language classes organised by the Hong Kong Consulate-General of Portugal. That Republic's Macau citizens, resident in Hong Kong, now saw a benefit in knowing Portuguese which had escaped them before.

As in much of the rest of Euro-Asia, if differently, the events of 1989/90 in countries with Communist governments led to major policy changes that have affected, do and will affect Hong Kong. These included Hong Kong government initiatives to dispel the crisis of confidence that took hold after 4 June 1989. Thus, in his 1989 Governor's October policy speech, Sir David Wilson announced new programmes. One was to construct Hong Kong's new airport. Workers from China, Thailand and Hong Kong are now finishing the Tsing Ma suspension bridge for the new airport's road and rail traffic. Its towers are 200 metres high; its span exceeds that of San Francisco's Golden Gate bridge! The airport's eventual target is to handle 87 million passengers annually. ${ }^{1}$

Another programme announced by David Wilson provided for enough extra first year first degree university places to be created for all qualified school leavers to be able to enrol in tertiary programmes by September 1994 . Ten years ago only $3 \%$ of secondary school students went on to tertiary studies, whereas today the figure is about $18 \%$. The most dramatic, perhaps final, increase for the foreseeable future began in 1989 .

Such programmes make Hong Kong more and more international and cosmopolitan and increase the diversity of languages among its inhabitants along with the necessity for lingua francas. The need for multilingual or, at least, bilingual people in Hong Kong is also growing. This demand for linguistic skills is being met, but not as quickly as Hong Kong employers' expectations of language competence rise.

The recurrent and very public disagreements between the governments of Beijing and Taipei and between the governments of Beijing, Hong Kong and London reduce the openness of each of those places to people, goods and services from the others. However, the already considerable and growing number of exchanges between these places is less well publicised. Taiwan travellers must find it tedious, time-wasting and costly to fly south to Hong Kong, to change airlines there and then to fly north to Shanghai. Yet alongside these inconveniences is a burgeoning of Taiwan investment in mainland China, of trade between the two parts of China and of the movement of people from Taiwan travelling between them. Hong Kong benefits from this traffic, not least culturally: more Mandarin is heard in Hong Kong and more Taiwan people use some Cantonese.

The Taiwan group Music Factory illustrates such benefits. The song Huánghòudàdàodong (Queen's Road East, a part of Hong Kong Island) was hugely 
popular in Hong Kong in 1991 and is still widely heard. Music Factory, a Taiwan group, recorded the Cantonese Song that was written by Law Tai Yau, a lyricist and singer from Taiwan who works in Taipei and Hong Kong. On the Japanese-made CD the title's romanisation rests on Mandarin, but the lyric is Cantonese with a sly humour. So, it suggests that after 1997 some place names must change: maybe the anglicisation 'Mong Kok' will become 'Wong Kok' (a better approximation of the name of that part of Kowloon.) The song has no comment on the road name that provides its title. Equally, Music Factory's Mandarin songs have been successes in Hong Kong. Conversely, Hong Kong recording artists, like Anita Mui, have packed concert halls in Singapore and Taipei where Cantonese has no great standing.

Hong Kong has become one of the world's richest economies: its per capita domestic product now exceeds that of Australia or the UK. In 1994 primary production was $0.2 \%$ of gross domestic product. Correspondingly, virtually everything that Hong Kong people need or that they work on to make money comes from elsewhere. Exports or re-exports pay for all these imports. So it is only slightly surprising that small and over-crowded Hong Kong is the world's eighth largest trading entity. Vast trade draws people: four million people, from over 10 million, who visited Hong Kong in 1995 came from mainland China or Taiwan. The other six million who came for trade, business travel and tourism helped to make Hong Kong one of the most thoroughly international places there is. The numbers of travellers to and from Hong Kong accords with its having become predominantly a service economy. More than $72 \%$ of its workforce is in tertiary production; a growing number of them arranging for the manufactured goods once made in Hong Kong to be made in China now and sold worldwide. This tertiary sector grow th correlates with Hong Kong's overseas representation: the Trade Development Council has over 50 offices in 34 countries; the Tourist Association has 18 overseas offices; the Industrial Promotion Unit maintains just seven. Hong Kong's financial services are remarkably developed and widely used: at the end of November 1994 its hundreds of financial institutions held US $\$ 590$ billion, estimated to be $8 \%$ of the world's bankable wealth. At the end of 1995, Hong Kong had 68 telephones for every 100 people, 663,000 cellular telephones and a monthly growth rate of $3.66 \%$ for the number of such gadgets. The classified pages of Hong Kong newspapers commonly carry adverts in German, French and other languages beside Chinese or English and next to adverts from jurisdictions other than Hong Kong or China. The international character of Hong Kong goes beyond its commercial enterprises. More than 15,000 Hong Kong children and young adults go to overseas schools, colleges and universities.

Undoubtedly, the cultural life and recreational pursuits of the people of Hong Kong are deeply rooted in Chinese traditions and art, from mahjong to calligraphy and tai chi. Equally, their entertainments are undeniably international. American, British, German, Russian, and Japanese companies, performers and exhibitions continually fill Hong Kong's galleries and auditoria. Thirty-eight Chinese language daily papers and five major English ones are printed and sold in Hong Kong. The periodical press is yet more plentiful and includes publications in Asian languages, like Tagalog — over 130,000 Philip- 
pines citizens live in Hong Kong. Hong Kong is the third largest film making centre in the world and where some internationally famous film actors and directors began their careers.

The international character of much of Hong Kong, its recovery and great expansion after occupation and its modernity should by now be clear. Within the bounds set by laws, particularly immigration laws, and occasionally outside them, Hong Kong is a society open to people, ideas, goods, services and change. Not everybody in Hong Kong is rich; some, including a disproportionatenumber of old people, are certainly poor, but the territory is successful economically and affords often good, though commonly stretched, amenities and support for its inhabitants. Its weakest point is probably the price of housing: US\$500 per square foot is a typical price for a flat. Few Hong Kong people live in a house.

This is one account of the background to language change in Hong Kong but another is necessary or its whirl, energy and kaleidoscopic variety will hide enduring values, a proven resilience to adversity and an ability to sustain and, when apt, enjoy traditions rooted in China, especially southern China. This second account follows.

\section{The World's Greatest Cantonese City}

Arguably, although rarely claimed explicitly, Hong Kong is the greatest Cantonese city that the world has ever seen. The claim is important in its own right. In The Ethos of the Hong Kong Chinese, Lai \& Kuan (1988) reported that 62.6\% of respondents 'recognised the presence of the public interest, whereas only 21.1 $\%$ repudiated the idea of public interest'. (Page 55) These figures may come as a surprise for a place whose people Anthony Sampson (1990), in The Midas Touch, described as more dedicated to money than those anywhere else on earth. This view accords with Lai \& Kuan's finding that making as much money as was legally possible was the most important personal goal. Admittedly, figures from their survey showed health, not income, as the most important element in a happy life, although $81.4 \%$ said that money was important in a happy life. Such data suggest that in Hong Kong, as in the USA, a person's wealth is a measure of his, or her, significance as a person. At the same time, the relevance of public interest for Hong Kong people is also repeatedly borne out. For example, they gave the equivalent of over US $\$ 300$ million to alleviate the effects of south China's floods in 1993. Of course, the two concerns can go together: a person who publicly gives half a million dollars to flood relief gains much face. The resources that underlay Hong Kong's donations to flood victims provide one reason for seeing Hong Kong as a greater city than Guangzhou (Canton) which, if bigger, is poorer, less well-organised, less safe, less international and less free, although much older. Macau is far smaller, also poorer and less well organised but about as free, fairly international and nearly as safe, although again older. To be the greatest of three does not sound much; it barely licenses the superlative degree. Yet those three include two with over six million people and even among the packed and populous cities of today's world not many are so large. Cantonese is widespread in cities such as Kuala Lumpur and Vancouver and has over 1000 speakers in 65 countries (Wang Gungwu, 1994) and Hong Kong people are free, affluent and 
numerous enough to travel to many of them and help make their city the principal focus of overseas Cantonese.

Some of these points could, it may seem, be set aside by noting that Hong Kong has been and will be part of China, that many of its inhabitants were born there and that if other Chinese cities were as economically successful then their inhabitants, too, would be comparably generous. This observation is fair - as far as it goes. Its reach is limited because it does not acknowledge the proportion of Hong Kong Chinese people who say that they are 'Heung Keung yan', 'Hong Kong people', not 'Chung Gok yan', Chinese people (cf. for example, Lai \& Kuan, 1988) Such a choice may be better seen as a recognition of its maker's identity than as a repudiation of his or her ancestry or origins. The grounds for such recognition are several. One is awareness of the ease with which Hong Kong people can, or feel they can, spot a visitor from the PRC. Another is the vigour of Cantonese in Hong Kong.

This vigour is not always welcome. Yip \& Matthews (1994, 3), writing of popular novels, note that, 'Due to the low status of written Cantonese this new literature is frowned upon in traditional Chinese cultural circles but, like the use of Cantonese in pop songs, it appears to be generally accepted by speakers of the younger generation'. Standard written Chinese is taught in Hong Kong schools and used in academic settings but lacks characters for many Cantonese words and idioms. In informal writing, like newspaper gossip columns or novels and advertisements, written Cantonese, with its own characters, is often used and it can be impenetrable to non-Cantonese Chinese. Beijing visitors to Hong Kong who have to resort to English from arrival to departure innocently amuse their hosts (who may have converse and even greater difficulty in much of China). Hong Kong was traditionally part of Guangdong and now borders a Special Economic Zone within that province. Many people in Hong Kong have close family and business ties there, including some to its capital Guangzhou (Canton).

If one is going to be monolingual in Hong Kong, then speaking Cantonese will make everyday life much easier than speaking any other language. This reality together with British sovereignty over Hong Kong and the widespread use of English in activities important to Hong Kong (aviation, business, finance, legal matters, science and technology), has led to English and Cantonese being the official languages of Hong Kong. The Official Languages Ordinance (of 1974) recognised the two languages as of equal status for communication between the government or any public official and members of the public. For speech 'Chinese' here meant 'Cantonese' although the Hong Kong Civil Service very recently adopted the goal of a completely biliterate (Chinese \& English) and trilingual (Cantonese, English and Putonghua) staff. Conversely and because of the attractions and the strong economies of Guangzhou, Shenzhen and Hong Kong, Chinese from other regions are learning Cantonese with similar industry to that of the many Hong Kong people who are learning Putonghua to help them travel and work in provinces north of Guangdong. Their knowledge that what is happening is an exchange more than an imposition facilitates the process.

The vigour of Cantonese in Hong Kong is apparent in the uses to which its speakers put it, the rate at which its slang and idioms change and the confusion this causes for Cantonese speakers from elsewhere. 
In the 1950s written Cantonese was dwindling in the Cantonese speaking parts of the PRC (cf. Snow, 1993) but growing in Hong Kong, and the style known as 'saam kap dai' was used in Hong Kong by a number of popular writers and columnists. By the 1980s there were paperbacks written in pure colloquial Cantonese, and in 1987, 1988 and 1989 the books linked to the Cantonese radio show Diary of the Little Man were, Snow notes, bestsellers. He comments that the success of novels in written Cantonese, ' ... may well also be due to a ... sense among Hong Kong people of Cantonese as a symbol of Hong Kong's culture' (Snow, 1993: 15). Broadcasting in Cantonese in Hong Kong is important. Fifteen radio channels serve Hong Kong: the government's Radio Television Hong Kong (RTHK) has seven; Commercial Radio has three; Metro Broadcasting another three; STAR TV runs a satellite radio service and the British Forces Broadcasting Service its own service. The RTHK channel, Radio 1 includes Cantonese phone-in programmes on political and social issues. Thus, the manoeuvres of PRC, ROC and US forces in the Taiwan straits before the 1996 elections for the Legislative Yuan in Taipei tapped varied opinions and strong feelings from people phoning in. Cantonese is used on nine other radio channels, sometimes alongside English. Still other Hong Kong channels transmit in Putonghua, Tagalog or Japanese but, predictably and predominantly, Cantonese is the radio language of Hong Kong. The stations, some for 24 hours a day, broadcast to large and responsive audiences with a range of staples - from Cantonese opera and other cultural programmes (Radio 5) to listings of exchange rates and share and vegetable prices, interspersed with golden oldies, western or local (Radio 7).

Hong Kong television services are nearly as numerous as the radio channels and one or more reach almost every household. The technical virtuosity that sustains their sometimes less than virtuoso programmes and the complexities of the franchises, licenses and commercial or public services rationales that allow them to operate all develop bewilderingly.

The Cantonese phrase Moh lei tau refers to a way of talking in Cantonese slang. In the early nineties it made its originator, the television comedy actor Chow Sing Chi, both rich and famous. Moh lei tau made very little sense to Cantonese speakers. However, secondary school students and other members of the younger generation delighted in Moh lei tau. Many became fluent exponents of it. Many Cantonese-speaking teachers found no delight in it at all. Some of Hong Kong's great and good publicly appealed to the young not to desecrate their language, to respect their culture and to, please, avoid bringing about the end of civilisation, as Hong Kong knows it. The rage is over now; the role of television in starting it remains indisputable.

Canto-pop music and other music with Chinese lyrics can be heard unceasingly over radios, on television and in karaoke bars. Accordingly, music is a growth industry in Hong Kong. Its annual output is about two items for everybody in the place: 12.32 million CDs, tapes or records, in 1994. They were worth over US\$200 million with 70\% being Canto-pop or other Chinese language recordings. The overall figures have increased, by about $2.6 \%$ annually, for the last five years although some shift to more international music and a little less Canto-pop is discernible (cf. Target Intelligence Report, October 1995).

All in all, Cantonese is as intrinsic to Hong Kong as its being a port. It exists 
alongside English but has far more uses for far more people in Hong Kong, even though English and other languages are in everyday use and help sustain broadcasting, press, commercial and cultural activities.

\section{Conclusion}

What has not changed or changed little in Hong Kong since 1945 and is any of it linguistic? One answer is Qing (Ching) law; another is full form characters. For the 47 years since the PRC began Hong Kong has been able to remain apart from it. This may be because the decolonisation that the Atlantic Charter required was not meant to extend Communist territory; perhaps it has been because Hong Kong has long seemed sure to revert to Chinese sovereignty with the end of the 99-year lease on the New Territories. At that time the Qing dynasty still held sway, if shakily, and its legal system was to be available to the then inhabitants of what became Hong Kong's New Territories and to their descendants, although the option of recourse to much of British law in Hong Kong was also theirs. This co-existence, if incomplete, had consequences. In 1991, one consequence caught the attention and recruited the energies of some members of Hong Kong's Legislative Council, which for the first time included people like Emily Lau, elected for geographical constituencies, and appointed members like Christine Loh, with an arguably wider spectrum of interests than the appointees on earlier Councils. Over 80 years after its vermilion pencil signed the end of the Ching dynasty, the Legislative Council passed, while demonstrators outside were moved to violence, an Ordinance to enable New Territories landowners to bequeath land to a daughter, if they so desired. Qing law forbids such inheritance but the Council ended the prohibition; it too became extinct.

This example of change in new circumstances is not linguistic but it finds a parallel with the use in Hong Kong and Macau of full form characters for standard written Chinese, the received form of Chinese orthography. As Woon (1987) describes in detail, the characters used for writing Chinese have been evolving for thousands of years. They have, also, been systematically revised more than once. This most recently happened in the PRC where school children learn what are called 'simplified characters'. That revision, which Singapore imported, has had little effect in Hong Kong although simplified characters recently became acceptable for answering examinations set in its schools and Hong Kong people who travel to China gain from knowing simplified characters.

The continuing use of some Qing laws in much of Hong Kong and of full form characters and the steps to change even their status each echo the quotation cited above, 'Whatever was most urgent was done in the easiest and quickest way. Whatever could be postponed was forgotten for the time'. The quote acknowledges the immediacy of responses which people in Hong Kong show in pursuing change and at the same time leaves scope for their willingness to let matters ride when there seems little to gain from change. The case of Qing law illustrates this well. Few in Hong Kong who might have been able to change it, for example successive Directors of the Lands Department, or even those who might have been thought likely to wish to change it, for example families with land but no sons, believed Qing law's apparent anomalies were worth trying to change, if only because the attempt could well bring trouble without much profit. If a 
different person inherited some land there was still only as much land and Chinese cultural inclinations to favour boys over girls and men over women are only slowly lessening. These last points do not, in our view, yield an admirable argument but they do, in traditional terms, legitimate an inheritance practice for land that long prevailed. We can say that, before 1991, there was little pressure to select an alternative, should one be mooted. Other enterprises that looked more likely to bring rewards were pursued - or selected. Again, in linguistic terms, pressures favouring knowledge of English have been at work in Hong Kong for the last 50 years. Conversely, during the same period few pressures existed for abandoning full form characters.

The end of the cultural revolution and the introduction, from 1978, of the four modernisations and a market economy opened China to the rest of the world. Its best gateway has been Hong Kong. Because of these changes, determined outside Hong Kong, the abilities to speak Putonghua and to read and write simplified characters have, during the last 10 years, become increasingly worth acquiring. Similarly, as Hong Kong has moved from being, in 1946, a fairly rural society to one devoted to service industries, a knowledge of English has become more and more worthwhile. When the governments of the PRC and of Singapore firmly decided on simplified character orthography, the school children of those countries had to learn the new forms and lost opportunities to master the older ones. There has been almost no similar pressure in Hong Kong either against full form characters or for learning simplified ones. Access to the great numbers of books in such characters was a pressure for full form characters. Again, successive influxes of refugees were enough of a challenge for the expanding Hong Kong school system without adding to or drastically revising its curriculum.

The patterns of action, inaction and circumstance just outlined agree well with the remarks that 'Whatever was most urgent was done in the easiest and quickest way. Whatever could be postponed was forgotten for the time'. Now the time for fluency in Putonghua and simplified orthography cannot be long postponed ${ }^{2}$ and so there will be change in these areas as there has been in those that other papers present in detail.

\section{Notes}

1. For Britain the like figure against total population would be Heathrow annually handling more passengers than Europe has people.

2. On June 19th 1996 the Hong Kong Social Welfare Department published in simplified characters a booklet for then 150 daily newly arriving legal immigrants from the PRC The Department did so under pressure from members of the now entirely elected Legislative Council.

3. We are grateful to Dr Stephen S.M. Chung, Dr Samuel C.S. Leung, Mr William Y.C. Wan and Ms Lucinda K.P. Wong for help in tracing references we cite here.

\section{References $^{3}$}

Anon (1995) Survey: The Hongkong music industry ringing in the dough. Target Intelligence Report. October, 15-17.

Dorling-Kindersley World Reference Atlas (1994) Hong Kong, London: Dorling-Kindersley. Hong Kong (1947) Annual Report on Hong Kong for the Year 19461.

Hong Kong (1996) Hong Kong 1996. Government Publication.

Hong Kong (1996) Hong Kong Monthly Digest of Statistics. Census and Statistics Department, April, 1996. 
Hong Kong (1974) Official Languages Ordinance.

Jing, Q-c (1994) The Chinese single-child family and population psychology. (In a paper to Anniversary Conference). Abstract in 1993-1994 Hong Kong Psychological Society Handbook (pp. 33-34). Hong Kong: Hong Kong Psychological Society.

Lai, S-k. and Kwan, H-c. (1988) The Ethos of the Hong Kong Chinese. Shatin: Chinese University Press.

Law, D-y, (1991). Huánghòudàdàodong \{CD MFCR 9101 2\} Japan. Music Factory (Track 1).

Patten, C.F. (1995) Quoted in Frank-Keyes, J. (1996) Is higher education in Hong Kong too expensive? Profile Hong Kong Polytechnic University Quarterly Spring, 2-4.

Sampson, A. (1990) The Midas Touch: Understanding the Dynamic New Money Societies Around Us. New York: NAL/Dutton.

Snow, D. (1993) Chinese dialect as written language: The cases of Taiwanese and Cantonese. Journal of Asian Pacific Communication 4, 15-30.

Wang, G-w. (1994) Personal communication.

Wilson, D. (1989) Governor's policy address to the Hong Kong Legislative Council (delivered on 11th October 1989).

Woon, W.L. (1987) Chinese Writing its Origin and Evolution Macau, University of East Asia.

Yip, V. and Matthews, S. (1994) Cantonese: A Comprehensive Grammar. London: Routledge. 